\title{
Sound Postcards in Forced Displacement: Changes in the Social Fabric of Victims of the Armed Conflict in Colombia Based on an Analysis of Their Sound Environments
}

\section{Andrea Rodríguez-Sánchez}

Independent researcher, CuestionArte of Colciencias group, Colombia

Alberto Cabedo-Mas ${ }^{1}$

University Jaume I of Castelló, Spain

\begin{abstract}
The objective of this study was to analyse the changes in social fabric caused by the armed conflict in Colombia among people who had been the victims of forced displacement and who when arriving in the new places participate in a musical-social programme. The study was conducted using testimonies from interviews and in the form of sound postcards, an ethnographic research tool. Twenty-one interviews with 14 interviewees in the Music for Reconciliation (MFR) programme of the Batuta National Foundation (BNF) and their families were analysed, and 70 sound postcards, revealing the meaning of interviewees' sonic landscapes, or soundscapes, in their everyday lives. Their sound environments were found to have changed significantly; having been rural before forced displacement they became urban, and there were also changes in interviewees' social bonds with people and relationships to objects in the environment. The study reveals a significant change in their sound landscapes before and after forced displacement and analyses the impact of these sonic landscapes and their meaning in the everyday lives of the participants. Finally, the use of sound postcards highlights MFR music centres as places where displaced people can be helped to form new bonds. The sound environment

\footnotetext{
${ }^{1}$ Corresponding author:

Alberto Cabedo-Mas, Faculty of Human and Social Sciences, Universitat Jaume I. Av. Vicent Sos Baynat, s/n, Castelló 12071, Spain.

Email: cabedoa@uji.es
} 
of these music centres give meaning to music making, generating positive feelings and providing participants with an emotional support network.

Keywords: Social fabric, collective musical spaces, sonic ethnography, soundscapes, socio-acoustics, sound postcards, armed conflict, Colombia.

Our knowledge of the world in which we live comes from our sensory channels, through which we register and build our identity and memory (Pitarch, 2004). However, Western culture has placed an emphasis on the visual channel, prioritising it over the other senses when shaping realities (Llorca 2017). This same omission is found in the academic field, whereby methods making use of senses other than sight are rarely used (Müller, 2012; Smith, 2000). This contrasts with the pre-eminence of the oral channel (i.e., the spoken word) in everyday life (Pinch \& Bijsterveld, 2012; Sterne, 2003) although Schafer (1969), in his introduction to sound studies, and Simmel (1997), on the sociology of the senses, have unquestionably encouraged academics to consider sounds as important systems of meaning that help to transmit, reify or challenge socio-cultural norms and values (Brandt et al., 2009; Feld, 1996; Gershon, 2011). For example, sounds can "inform the ways in which people understand their relationship to the spaces and places, understandings that strongly contextualize the ways in which individuals constitute their identities" (Gershon, 2011, pp. 66-67).

Jean-François Augoyard (1995) investigated the construction of social bonds and their relationship with the sensory channels through which a group perceives its environment. Similarly, Alonso-Cambrón (2014) suggests that sounds and listening to sounds be subjected to sociological analysis so as to make a contribution to the social 
sciences. These ideas promote reflection on the importance of sounds as a source of information, and the possibility of developing sound-based research methodologies.

Building on the results of previous research (Rodríguez-Sánchez, 2019), an analysis was made in the present study of sound postcards, an ethnographic research tool, to gain insights into interviewees' perception and interpretation of the sound environment of the Music for Reconciliation (MFR) programme of the Batuta National Foundation (BNF). This analysis was used to understand interviewees' social fabric, defined as an individual's network of relationships, including the tangible and intangible resources that can meet their biological, affective, social, and spiritual needs. Through these relationships, the individual shapes their identity, constructs their life plans and acquires the values that equip them to exercise solidarity and social commitment (RodríguezSánchez et al., 2018a).

In Colombia, the social fabric has been affected by armed violence for decades, with dire consequences. According to the National Historical Memory Centre (Centro Nacional de Memoria Histórica-CNMH, 2013), ten per cent of Colombians were forcibly displaced between 1958 and 2012, following violent actions such as group massacres or the selective murder of individuals accused of collaborating with an armed group. Fear and mistrust have therefore come to characterise social relations (Quinceno \& Orjuela, 2017). A continuum of death has been constructed, as a social rather than as a physiological fact (Taussing, 2002), ushering in what Pécaut (2001) calls the non-place in which the individual and group lose their ability to forge an $I$, a we.

In this context, silence becomes a characteristic of both relationships and territories. In Colombia, armed actors ${ }^{2}$ control, even of people's conversations, made

\footnotetext{
2 There are various actors involved in the Colombian armed conflict. According to https://www.colombiaarmedactors.org/, armed actors include government forces, insurgent organisations, paramilitary groups and criminal organisations. Those include groups with political interests (e.g., guerrilla groups) and with economic interests (e.g., paramilitaries and drug-traffickers).
} 
silence a kind of protection against becoming enmeshed in the conflict (Villa, 2006). In this way, silence was at once "defence and conservation, [as well as] the main mechanism for propagating the culture of fear" (Taussing, 2002, p. 30). A shift in the sound environment thus took place, related to changes in daily life. This can be seen as a result of armed violence creating non-places, described by Augé (1993) as places lacking the conditions in which identity, relationships, and history can be created, and that are therefore associated with anonymity. Silence, non-places, and anonymity characterise the sense of isolation experienced by the victims of violence, both in their original locations, where the social fabric had been torn apart by the armed actors, and at the victims' final destinations. Displacement shapes non-places, constraining the sharing of lives and the construction of bonds (Villa 2006; Rodríguez-Sánchez, 2010).

In an attempt to address the consequences of the conflict, the Colombian government introduced a policy of providing care for the victims of forced displacement (Ibáñez \& Velásquez, 2009). The MFR programme, supported by the Colombian Ministry of Culture, is one outcome of this policy. Its main objective is to enrich the lives of children, adolescents and young adults by delivering high-quality music training according to a model designed to guarantee the exercise of the cultural rights and the holistic development of the victims of conflict (BNF, 2016). Community music making has already been shown to promote the well-being of the victims of armed violence (Cabedo-Mas, 2015; Craig, 2019; Howell, 2018; Odena, 2010; Osborne, 2012; Pruitt; 2011; Zelizer, 2003), and there is evidence that the MFR programme, in particular, has had an impact on the reconstruction of its participants' social fabric. The aim of the present study was to add to the existing findings with an analysis of their testimonies and the sound postcards. 
In social sciences research, the study of sounds is typically represented by acoustics: research on the physical characteristics and processes of sonic phenomena. Some authors have focused on the sounds of life, which, according to Krause (2008), are threefold: the sounds of the earth and plants (geophony), the sounds of the living organisms that inhabit those places (biophony), and those produced by human beings (anthropophony). Within the category of anthropophony, Alonso-Cambrón (2005) explored the concept of sociophony, which encompasses the sounds produced by all living beings endowed with auditory systems, including humans, and their relationship with interpretive or hermeneutical systems.

Ethnographic researchers have studied sonic elements such as noise (Hall et al., 2008), soundscapes (Findlay-Walsh, 2018; Rosenblum, 2013), and music or sound art, often focusing on musical behaviour rather than the musical context in which behaviours are witnessed (Feld, 1984; Lacey, 2016; Lomax, 1976). Drawing on this research, AlonsoCambrón (2005) refers to the imaginary sounds that accompany our realities and are therefore part of our contexts, our ways of life and, consequently, of our identities. He suggests that hearing sounds enables us to recognise in a given environment "aspects that range from the morphology of those environments and atmospheres (physical, urban design, architecture) to the chemical and cultural processes related to cognition and the construction of reality" (p. 53).

The sounds of a place, and the way its inhabitants describe them, can give us a sense of the way its features relate to their identity, culture and meaningful relationships (Llorca, 2014). Sounds as acoustic phenomena and the stories about them - that is, their assimilation into the social imagination or their interpretation within given hermeneutic- 
cultural dynamics - can indicate what people believe is important in their daily lives and therefore the meanings to them of places and relationships (Mills, 2004).

According to Alonso-Cambrón (2011), ethnographic research in the field of socioacoustics is approached on two levels: objective-descriptive and interpretative. At the objective-descriptive level, the sound environment, or sounds in a particular place, is the focus of research. These sounds can be considered sociophonic phenomena because they stem from interactions between living beings. At the interpretative level, the focus of research is the way people in the place containing the sound environment perceive and assess the sounds themselves.

We believe, therefore, that psychosocial as well as physiological and physical variables contribute to the communicative aspect of sound. These psychosocial variables include the culture, in which sonic phenomena are produced and perceived. That is, people can use sounds to appropriate the places in which they live, or territorialise them (Deleuze \& Guattari, 1983). Llorca (2014) introduced the notion of sound territories, defined as "a system of sound-spatial relations which are fundamental for inhabitants' adaptation to the environment, a system made up of a spatial complex delimited and interconnected by sound networks and flows that characterise it" (p. 181). Provided the individual is aware of the sound environment in which they live, they can describe this relationship between place and sound through soundscapes (Schafer, 2013). A soundscape is captured when it is detected as a result of conscious listening and becomes the focus of attention (Llorca, 2017). When we listen to sounds consciously, with our whole bodies (Nancy, 2007; Kahn, 1999), the meanings with which they are associated including emotional connections, biological responses, and personal memories - activate our sense of belonging (Truax, 2001; Duffy \& Waitt, 2011). 
It is important for ethnographers to listen in this way (i.e., consciously) when they seek to understand the context of the data they are gathering (Forsey, 2008). Similarly, Back (2003) points out that awareness of sound, which lies beyond the visible and apparently static world, highlights its changeability and underlies the temporary nature of social life.

The study of socio-acoustics recognises sound spaces and is therefore capable of revealing the elements of inhabitants' soundscapes and enabling others to grasp their associated meanings. In this way the concepts of sound territories and territorialisation are merged (Alonso-Cambrón, 2014, 2018). Research on conflict and identity has made use of the study of sounds as a way of understanding topics such as relationships, trauma, survival, and resilience (e.g., Bergh \& Sloboda, 2010; Daughtry, 2015; Grant, et al., 2010; Lederach \& Lederach, 2010; Rodríguez-Sánchez \& Cabedo-Mas, 2017; Urbain, 2008; Wood, 2006). Drever (2007) explains the place - as an acoustic space - is the point where sound and culture meet.

In the present study we expected the study of sound to reveal participants' places, the meanings of the sounds associated with them, and the identities they had constructed from those places and sounds (Alonso-Cambrón, 2005). To understand individuals' soundscapes it would be necessary to use methods sensitive to the identities arising from them (Butler, 2007).

\section{Methodology}

\section{Design and materials}

A qualitative study involving in-depth interviews (Kvale, 2011) was conducted. Each participant in the research was interviewed three times. During the course of each interview the sound postcard was used as a tool for eliciting interviewees' life histories, 
exploring in particular their experiences before (BFD) and after forced displacement (AFD), as well as their current experiences of participating in the MFR programme.

The sound postcard is a sound ethnography tool originally developed by Claire Guiu of the Ciutat Sonora research group at the Catalan Institute for Anthropology ${ }^{3}$ (Alonso-Cambrón, 2011) for the purposes of sound ethnography. It asks research participants to describe the sounds associated with particular places with the aim of capturing their perceptions of their sound environments (see Data analysis for the specific question asked). We carried out a pilot study to ensure that the sound postcard would be suitable for use with participants in the MFR programme, as they were children as well as members of a displaced population, and therefore especially vulnerable (RodríguezSánchez, Odena \& Cabedo-Mas, 2018). The results of the pilot study showed that the sound postcard was a valuable research tool with the potential for illuminating interviewees' narratives by revealing changes in their social fabric.

\section{Participants}

Intentional sampling, carried out in conjunction with experts working in MFR's music centres in Bogotá, Cali, Florencia, and Tierralta, where an ethnographic study had been conducted, was used to select 14 interviewees: seven children and young people taking part in the MFR programme, and seven of their family members. According to Erben (1998), participants should have an affinity with the topic being researched and the time to participate in the study. In the present study the selection criteria were that interviewees (1) belonged to a community that had fallen victim to the armed conflict; (2) were taking part in the MFR programme; (3) had been affiliated with the MFR programme for at least a year; (4) were over the age of ten; (5) had the time to take part in the research and (6)

\footnotetext{
${ }^{3}$ https://www.antropologia.cat/
} 
had given their consent for the information they provided to be used for the purposes of research. Table 1 shows the number and status of individuals interviewed at each of the music centres visited.

Table 1 here

Ethical approval for the research was granted by the University Jaume I Ethics

Committee. The interviewees' names have been changed to maintain their anonymity.

\section{Data analysis}

Twenty-one interviews were conducted in which the following question was asked: "If you had to send a picture of the place we are talking about to someone who has never been there, but the picture was made of sounds, what sound or sounds would you choose to send them?" From these interviews, we selected and generated seventy sound postcards were generated in response to this question. A selection of these postcards was chosen to form the basis of a gallery of sound postcard illustrations, to be used for disseminating the results of the study and thus allowing listeners to connect with the experiences of the interviewees (Lacey, 2006). These illustrations consist of excerpts of the recordings of the interviewees' testimonies, using their own voices and accompanied by sounds that were intended to be related as closely as possible to the interviewees' regions and the sound environments they described, although they had not necessarily been recorded in situ, so to speak, so were not necessarily entirely faithful (McCartney, 2010). The interviewees did not choose the sounds included in the sound postcard illustrations themselves. The designers of the illustrations were, however, aware that the choice of 
sounds had to be made with due regard to research ethics, given their impact on listeners (Westerkamp, 2002), and each sound postcard was later shared with the interviewee, to give the right to approve the soundtrack (Rodríguez-Sánchez \& Cabedo-Mas, in press).

Interpretative phenomenological analysis (IPA) (Smith et al., 2009) was used to code and analyse the data from the interviews, including the sound postcards, seeking to identify in interviewees' life histories their understandings of human existence as they experienced and understood it (Schwandt, 1990). The analysis was carried out by the two authors independently, in the first place; it consisted in generating and clustering the themes that appeared in the histories (Polkinghorne, 1995).

In addition to this qualitative analysis, descriptive statistics were obtained. First, the numbers of times each interviewee mentioned a particular sound were tallied and grouped to show the percentages reported by all interviewees to have been or to be relevant in each of the three periods in participants' lives: BFD, AFD and "at present."4 Second, the sounds and their associated feelings were categorised into three thematic categories that had emerged in a previous study (Rodríguez-Sánchez et al., 2018). Each category represented a different aspect of social fabric: networks, resources and bonds. Finally, an evaluation was made of the interviewees' relationships with the sounds reported for each period of their life history and the implications of these relationships for their networks, resources and bonds. The findings were interpreted in the light of Augé's (1993) indicators of the existence of a social place, linking the construction of identity, relationships, and history.

\section{Results and Discussion}

\footnotetext{
${ }^{4}$ The study was carried out in 2016 .
} 
In what follows we report the numbers of times each sound was mentioned in the sound postcards as having been relevant to an interviewee BFD or AFD, or as being relevant at the time the data were collected. We summarise the main themes arising from the analysis supported by quotations from the interviews and excerpts revealing the meaning of the sound environments described by interviewees. In this case, each of the quotations is accompanied by a QR code so that readers can hear the interviewee's voice, accompanied by the sounds chosen by the designer of the sound postcard illustration.

\section{Before forced displacement (BFD)}

Thirty sound postcards represent the soundscapes of the interviewees' original homes. Given that these derive from memories of the period before the forced displacement, the majority consist of testimonies from the relatives of the children and young people who were participating in the MFR programme. Some, however, include testimonies from young people over the age of 16 who had experienced the violent acts when they were children. ${ }^{5}$

As shown in Figure 1, the sounds to which interviewees referred most often in the postcards BFD related to the following themes: (1) nature, (2) human voices, (3) music and (4) domestic life.

Figure 1 here

Nature

\footnotetext{
${ }^{5}$ Several of the families who were interviewed had been victims of the flaring-up of the armed conflict between 2002 and 2010 when the civilian population was highly affected.
} 
As shown in Table 2, the sounds referred to most often in relation to the soundscapes of life BFD were those of nature. Interviewees clearly found being in nature of great value to them. They related to it in an intimate, contemplative way, so their evocations of nature were tinged with nostalgia.

Table 2 here

In several testimonies, interviewees reported that their happiest memories were of life in the countryside.

Let's see, my favourite sound from when I was a child was going up the mountain to hear the birds or the waterfalls, where the streams of water fall and you can hear and feel the streams of water, like that coolness and the birds singing. So that was my favourite sound, because I really loved it when my grandmother would chastise me and was going to hit me. I would go there, I

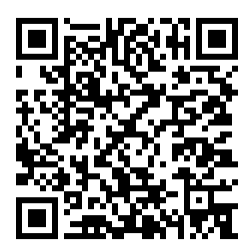
would take off, running, and there, in a waterfall there, I would sit down and cry or grumble, listening to the water and listening to the birds fly. Nature is what I've always liked, so in the middle of the city, in the middle of all these houses here, I have always still identified with my countryside. To me the countryside has always been and will continue to be everything to me, it's been my favourite place. (Olga, 35-year-old, mother of Camilo, 1st interview, Bogotá)

In terms of its sounds, the environment BFD is territorialised, for the most part, by nature. The sounds of nature are intertwined with the dynamics of human beings who wake up to birdsong, listen to the lowing of the cows waiting to be fed, and go to bed hearing the sound of crickets. Their relationship with nature is a bond that forms a crucial part of their identity. Many interviewees still considered themselves countryfolk, naming the countryside as the place where they belonged, even though they were living in the city when they gave their testimonies.

The sounds that I would choose would be something that I've never heard anywhere else, except in the countryside. You hear a calm silence, but it's also the sound of the birds and the insects, which is something that, I would say for me, I would like to hear again and 
feel at home in again, because that would be my home. (Sergio, 17 -year-old, $2^{\text {nd }}$ interview, Florencia)

The postcards indicate that nature was important to the interviewees because it was a constant part of their days, their work, their use of time and the things that made their lives meaningful.

\section{Human Voices}

The sound postcards evoke the presence and voices of the people who surrounded and supported the interviewees BFD (see Table 3). Their social networks are shown to consist mainly of family (16), and friends or neighbours (14), although people and their voices could also belong to more formal networks and institutional spaces (6) such as school or work.

Table 3 here

In addition to the places populated by family members, friends and neighbours, the sound postcards provide a glimpse of a shared daily life that exemplifies the appropriation of time and space (Lalive, 2008):

The sounds would be the waves in the sea, when it's high and low, that's the sound. When it dries out the tide goes out, then you begin to hear like bubbles. The children swimming, the mothers yelling, some mothers talking, watching, others saying: "Don't do that, you're going to drown", but really it's like just part of the conversation. It's like the sound of the

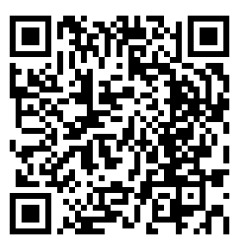
children in the sea. (Elizabeth, 40-year-old, mother of Alejandra, $1^{\text {st }}$ interview, Cali) 
Examples of postcards such as this one enable us to recognise that conditions were fostered in certain places BFD for gathering and closeness in everyday life; in these shared places the interviewees could engage in shared activities and develop a shared history. This is important because it shows the natural emergence of such places where people pass the time together and reveals an important characteristic of the social fabric BFD: through the creation of habits, social groups had acquired the knowledge of how to be together and do things together (Escobar, 2012).

Living in the village, when people were sharing the lunch they were making, at least it was boiling and you hear the fire there. They are serving and everyone is talking loudly so everyone can hear, kidding around, it's happy there sharing with everyone. (Lola, 36-year-old, mother of Pedro, $1^{\text {st }}$ interview, Bogotá)

\section{Music}

The music to which interviewees referred in the sound postcards BFD was notable because of its use at meaningful times such as births, the feast days of patron saints, Christmas, New Year and in the rites surrounding death (see Table 4).

Table 4 here

The postcards thus reveal the meaning of music in the interviewees' culture and traditions, particularly in relation to the marking of the rhythm of the year and each of the major events of the life cycle. They also reveal the involvement of interviewees' friends, neighbours and the wider community in the situations where music is made, emphasizing the role of music in sharing, celebrating, and strengthening bonds. In short, music has to do with others; it demonstrates connection.

You could hear the marimba playing, the marimba plays like the beat of the Petronio festival, but softly, something good is happening there, they're playing the marimba... Lots of hustle and bustle, like a festival, like music, laughter, chatting, cries of

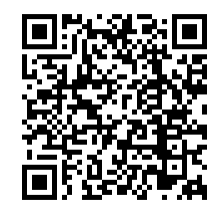


happiness. (Rosario, 42-year-old, mother of Héctor, $1^{\text {st }}$ interview, Tierralta)

Because celebrations are characterised by music, it evokes joy and happiness; references in the postcards to music reveal the places where encounters occur that are held in affection.

The sounds of Christmas are sounds of happiness, laughter, music, everyone laughing, everyone was happy. When the rain falls, it sounds like the rag doll being burnt, the children playing, the music, also the laughter, when people are talking... Well, that is what you could hear. (Alejandra, 10-year-old, $1^{\text {st }}$ interview, Cali)

Sonic phenomena also make it possible to glimpse traditional religious practices and their meaning in the lives of the interviewees.

When I'd go down to the village, suddenly you'd hear the sound of bells. No matter what happens, my grandma taught me to be a good Catholic. So, then I heard them, I realised it and said "Uh oh! The second round of bells is ringing". Sometimes we went running around and in the middle you could hear it, I would tell my siblings, "Run, run, it's the second round of bells, we're not going to make it" and stuff like that. The bells were like an authority. (Olga, 35-year-old, mother of Camilo, $1^{\text {st }}$ interview, Bogotá)

\section{Domestic life}

The final category of sounds identified in the sound postcards BFD were domestic, including food cooking and wood burning, in the kitchen and beside a river with a bonfire. These sounds portray a quiet, unhurried life in which time was spent on vital activities such as cooking and eating. They identify the histories and customs of people's everyday lives, framed by the landscape in which people listened to the burning of the firewood and watched the cooking of the food. The postcards reveal the abundance of food and the habit of sharing it; in short, the time and care spent on everyday life, which proceeded at a slow pace. 
The little birds, the cows, eh... the dogs. What else? My grandma cooking, the soup being made, the boys playing football down in the village. (Pedro, 17-yearold, $1^{\text {st }}$ interview, Bogotá.)

Specifically, the families' memories of the sounds they heard BFD revealed their feelings of calmness (5), joy (4), fun (4), enjoyment of home (2) and sadness or nostalgia (1). In general, the sound phenomena BFD evoke a quiet life surrounded by nature, with close relationships with family and/or friends. Perhaps one of the most remarkable features is that the sounds evoked were personal to the interviewees, in whose narratives could be identified the bonds between each sound and the interviewee's life history, for example in relation to nature, interactions and sharing with others. It was clear from their testimonies that interviewees felt a sense of natural connection with their environment, belonging to and participating in its dynamics. Other important elements of their lives BFD included the use of place and time, especially for encounters with others; engagement in rural activities; and taking time for themselves, and for contemplation.

\section{After forced displacement (AFD)}

The sonic phenomena evoked in the sound postcards referring to the period after the forced displacement show that interviewees' soundscapes changed substantially. All the families interviewed had lived in rural areas but, having become victims of the conflict, were forced to flee their homes typically for more urban areas, where they would benefit from the anonymity of the city. There they could start over again, seeking economic stability, and it would be harder for armed actors to find them.

As shown in Figure 2, the sounds to which interviewees referred most often in the postcards AFD related to the following themes: (1) human voices, (2) urban life, (3) 
music, (4) silence, (5) nature and (6) domestic life. We will focus on the themes that were more present.

Figure 2 here

\section{Human voices}

The voices that appear in the sound postcards AFD represent the voices heard in the sound environments of schools and, to a lesser extent, open spaces such as streets and parks. The voices are anonymous, unlike the voices of the family members and neighbours evoked in the postcards BFD. This reveals two major differences between the two periods of time: institutions were mentioned more often AFD, and both the interviewees and those they referred to in their postcards appeared to be anonymous (see Table 5).

\section{Table 5 here}

The voices heard in the sound postcards are associated with the interviewees' social fabric, primarily friends (10), institutional networks, specifically school and work (9), and to a lesser extent, family networks (8). The hustle and bustle of the city also includes the sounds made by anonymous people:

In the neighbourhood, almost every night you can hear music, you can hear people talking, laughing, that's what you hear. (Alejandra, 10-year-old, $2^{\text {nd }}$ interview, Cali) 
I can remember a river, a great river, it sounded harsh; so, I remember the sounds of the bus and the air conditioning, that's the only thing I remember. I also remember that there were people eating in front of us and we were like "Eww!" and the food wrapping... the sound of the wrapping... lots of cars honking, honking like crazy, and people walking, people's steps, and people... voices of people. (Pedro, 17-year-old, $2^{\text {nd }}$ interview, Bogotá)

The postcards AFD reveal social networks including close neighbours who provided assistance, as the interviewees' extended families had remained in their original homes. The life histories indicated that families were supported by new networks in new spaces including institutions, community organisations, schools, and communal dining halls.

\section{Urban life}

As shown in Table 6, the sounds of the street that were especially prominent were those associated with vehicles. The interviewees found the noise made by motorcycles annoying; it caused them discomfort. They also mentioned the sounds made by bicycle bells and buses.

Table 6 here

The children noticed the traffic in particular since it is not very common in rural life. Over time, however, they became used to it as background noise, wholly unconnected to them.

Before arriving at the river there was a guy with a house, I can't remember his name, I remember that he had grew pineapples, there were no roads there but instead things were transported by river... we left there and came here to Florencia... At first I liked it, I would

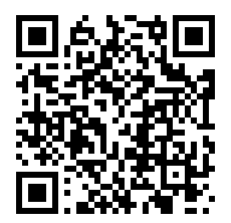


even go outside my home to watch the cars go by, but eventually it got boring. (Sergio, 17-year-old, $1^{\text {st }}$ interview, Florencia.)

Sociophonic dynamics reflect the interviewees' perception of the city as a hostile environment, its complexity apparent in the sounds of gossiping and fighting, for example:

Well, the sounds of the village, the music, squabbling, gossiping, because you go from one place to another and suddenly people are nosy, trying to see what they hear or heard someone say. People gossiping, but no the birds, because you can hardly hear any birds. (Esperanza, 52-year-old, mother of Sergio, $2^{\text {nd }}$ interview, Florencia)

Music

Music was described as omnipresent in the city, although often associated with other sounds in the environment: places were perceived as much noisier, the music being played at high volume in houses, bars, and elsewhere.

I would mention the music from my neighbourhood because there were lots of boom boxes playing, the motorcycle, the birds, the ruckus of the children playing, people yelling, and the noise made by the wind when it blows, that's what I'd put. Sometimes, too, the birds, the construction around the school, because construction is going on every day at school, all that noise. That's what I'd put. (Teresa, 13-year-old, $2^{\text {nd }}$ interview, Tierralta)

\section{Silence, nature and domestic life}

Silence is not related to a pleasant environment of calm but to loneliness and isolation. In a similar sense, domestic sounds like cooking, the sound of fire or the spaces of sharing around food decrease.

Finally, it is important to note the significant decrease in the number of references to nature, leading to questions about its place in the development of the interviewees' current identities, given that they repeatedly state how it is intertwined with the countryside. AFD, for example, the sounds of animals are reduced to domestic cats or dogs. 
Some of the things I enjoy the most during the day, when I am here, I like to look at the washing machine, or I like to watch the soap opera. When I am outside the house, I hear the sounds of children playing, cars, people talking... the rest is silence. (Lola, 36-year-old, mother of Pedro, $3^{\text {rd }}$ interview, Bogotá)

Generally, the sound postcards AFD reveal changes in the composition of the interviewees' social fabric: as well as fewer references to nature, there were fewer references to the voices of family and community members, and more references to the new friends who had become the interviewees' main companions. The new dynamics of the urban environment were represented by the cacophony of voices of the passers-by and other human sounds; their cars and motorcycles; and the loud music emanating from bars and other kinds of establishment.

The sound postcards also illuminate the characteristics of relationships with other people. These were marked by tensions indicated by signs of mistrust and distance between neighbours. The interviewees did not always experience bonds with the sources of the sounds they perceived, representing a rupture with their environment. Not surprisingly, almost all the postcards included references to the interviewees' nostalgia for their previous lives.

\section{The Music for Reconciliation programme}

When evoking the sound environments of the MFR music centres, interviewees referred to musical instruments (12), the songs they sang, which had been composed specially for the BNF (6), the concerts they gave (3), the voices of their teachers, laughter, conversations and the classes in which they participated (2) (see Table 7).

Table 7 here 
The postcards reveal the soundscapes in which the children felt immersed, including sounds from the street as well as the classroom; the presence of their teachers and peers; and the feelings associated with music practice.

I would say that the music we sing here, when we hear the sound of the fans, sometimes we have to turn them off because we're singing choir songs and they are really loud. The noise of the motorcycles, when cars go by, when they go by with some warning, the flutes we play. Sometimes when we play drums, the

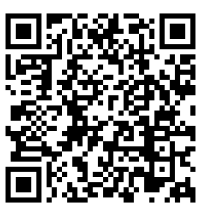
triangle, percussion. I would show all of this. (Teresa, 13-year-old, $2^{\text {nd }}$ interview, Tierralta)

These sound postcards also show the impact of music on participants' emotions; the interviewees spoke about it as a positive experience and one that seems to have generated a sense of unity with their peers.

Laughing, music, the Pink Panther, Conny the teacher and the concerts, singing. There are songs that you remember, you sing them and remember. There's one called Vivo en un pais, por la luz del amanecer, cantemos todos juntos ... that's why we sing together today here... singing that song we'd look at each other

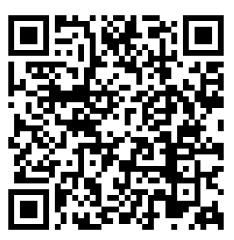
and almost start crying. (Pedro, 17-year-old, $2^{\text {nd }}$ interview, Bogotá)

The postcards mention songs that were particularly relevant at significant moments in the lives of the participants and their families, such as concerts. This suggests that music practice was important to the interviewees and the formation of their identity, the development of their knowledge of music, and the possibility of finding a space in which they could be recognised and feel valued. Some of the postcards include references to the emotional benefits of participating in an MFR programme:

I would send the concert, the final one, it was kind-of the most important one I've had since I've been here in Batuta. There was the piano, the guitar, different kinds of percussion instruments, the drums and a harp we used in the song Canta Llano ... songs: Canta Llano, Vivo en un País, Garundeo... I think that coming here has changed me considerably, my

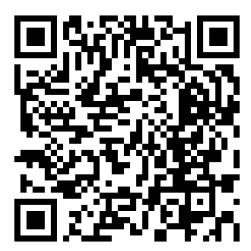
friends have changed me... I think they made me happier. (Camilo, 17-year-old, $3^{\text {rd }}$ interview, Bogotá) 
The soundscapes of the interviewees' classes consist of laughter, conversations, and teachers' explanations. The postcards convey the atmosphere of the place, the kind of relationships developed, and the interviewees' motivations for being in the programme. They also reveal the potential for the repertoire that is taught to help the participants feel connected to traditional music.

There are the sounds from when people are talking, laughing, you can also hear instruments, when the teacher is talking, the guitar, that's what you hear. My favourite song is one called $L a$ Niña Cumbia. No, I didn't use to like music, I didn't like to dance, so Batuta [the MFR] has released an emotion inside me,

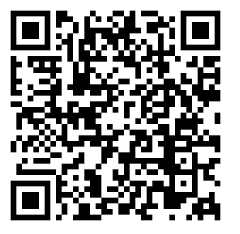
a talent, something I wasn't even aware of. (Alejandra, 10-year-old, $2^{\text {nd }}$ interview, Cali)

While these postcards refer to the sounds that are typical of the MFR music centres - instruments, songs, the voices of the participants and their teachers - they also shed light on relationships between people, and the feelings they evoked in the interviewees. Once again, then, the postcards reveal not only sounds but also bonds, providing glimpses of warm relationships between the people who meet at the music centre, the dynamics between them counterbalancing the tension associated with participants' relationships in their neighbourhoods. These bonds can also be seen in the joy, the fun and the participants' feelings of being recognised.

Overall, the sound postcards describing the life of the MFR music centre demonstrate the programme's capacity for generating positive experiences and feelings in its participants, and to provide them with a meaningful support network.

\section{General Discussion}

The sound postcards reveal a series of contrasts between the sound environments before and after the violent acts, which also reflect the life changes experienced by the interviewees. Barthes and Medrano (1986) describe the familiar sounds with which 
human beings mark out their territory as a domestic symphony. Indeed Augoyard (1995) refers to the sounds that are specific to places, and that enable places to be recognised, as sound markers.

The sound environment of the interviewees BFD consisted of the sounds of nature, the voices of people close to them, the music of meeting places, and even silence. In contrast, their sound environment AFD consisted of the sounds of constant traffic, the voices of acquaintances and strangers mixing with each other, and background noise including loud music in markets, homes and bars. The sound postcards and interview data can be analysed at three levels: 1) the sounds mentioned in the postcards can be described; 2) changes in the quality of bonds from one time period to the next can be inferred and interpreted, and 3) processes underlying territorialisation via sound in each setting can be identified.

At the descriptive level, the sound postcards revealed changes in some elements of the social fabric, including the interviewees' support networks, their uses of time and space, meeting places, and the emotions associated with the different experiences they recounted. The support networks changed in that the postcards BFD described the sounds of everyday activities, meetings and celebrations, and the voices of family members; by contrast, the postcards AFD described the sounds of institutional activities, and the voices of teachers and friends.

The sounds show a change in the predominance of support networks. BFD, the postcards portrayed the voices and activities related to family bonds. They described sounds related to everyday activities, as well as celebrations or shared meeting points. This changes AFD, with institutional networks and friends predominating, and a decline in the number of references to family bonds. This can be explained by the loss of contact with family members who had remained in their original homes, or who had become the 
victims of the violence and died. Another change was in the interviewees' awareness of nature, a network resource whose loss indicates another shift in their life dynamics.

Revisiting Krause's (2008) categories, we can see that geophony and biophony dominated the interviewees' soundscapes BFD while anthropophony dominated them AFD, once they had fled their rural homes for the city. The sound postcards illustrate the difference between rural and urban life and enable us to grasp the interviewees' sense of disorientation; they did not feel at home, but as though they were in a strange place. We can also infer that the country lifestyle described in the postcards BFD entails certain ways of using time and space associated with cultivating the land and deriving sustenance from it. The city lifestyle was very different in terms of the way that time was used and the activities that were carried out to provide for the family.

At the interpretative level, there were differences between the types of bonds that can be inferred between the interviewees and the sounds they mentioned BFD and AFD. One example is the sound of the music that was described. In the country, BFD, music was associated with births, the feast days of patron saints, Christmas, New Year and in the rites surrounding death. In the city, AFD, music was associated with constant background noise, including loud music playing in homes, shops and bars. Having been part of significant occasions in the country, it had become omnipresent in the city, a feature of the sociophonic dynamic common in the urban environment. It no longer had a social cohesive function, so the interviewees' relationship with it had changed. Similarly, the voices evoked in the sound postcards BFD were those of family and friends; AFD, they were anonymous and part of a cacophony. Even though interviewees referred to the same sounds in their postcards BFD and AFD, their connotations and thus the bonds between interviewee and sound were different. Their referents of meaning and belonging 
changed (Chaparro \& Bello, 2010) as did their domestic symphonies, associated with their original homes BFD and the new places in which they found themselves AFD.

Finally, the postcards reveal the processes underlying sound territorialisation (i.e., the appropriation of a place, using sound, by its inhabitants). Different territories are territorialised in different ways. On the one hand, the sounds of nature, integrated harmoniously with human sounds, territorialised the interviewees' homes BFD. The postcards describe a domestic sociophony consisting of the sounds of animals, water sources, and the voices of the family, merged with the raised voices of farmers and villagers communicating from a distance. On the other hand, the voices of the family cannot be distinguished in the interviewees' sound environment AFD. The sounds of the activities of other human beings filled and territorialised the places they now lived. Their postcards reflected changes in their rhythms of life and use of time and space, the absence of nature, and their chaotic city existence.

These analyses of the sound postcards and interview data show how the armed conflict constructed non-places for their victims, not only by forcing them to abandon their territories but also by breaking or removing all the referents that allowed them to find their place in society.

The postcards referring to the MFR programme, however, suggest that music and music making seem to be ways of re-territorialise the participants' new environment. This re-territorialisation occurs not only by filling places with sound but also by providing an environment in which people can form bonds with music and each other, helping them adapt and appropriate time and space in ways that promote a sense of normality (Lalive, 2008). The use of musical instruments, the singing of songs, and the enjoyment of laughter and concerts are all ways in which participants can find their places again, having felt as though they were shipwrecked in a cacophonous sea. These strategies form a non- 
violent counterbalance to the silences imposed by the armed actors, both BFD and AFD. Membership of the MFR programme enables children and young people to forge bonds with each other, their families, and the history of their families through making music, establishing relationships centred on music, and learning a repertoire connected with the country. As music making enables participants in the programme to forge these bonds so sounds are tied once again to meaning.

Finally, although interviewees were not asked explicitly about their feelings in the question designed to generate the sound postcards, they often talked about the emotions they experienced as they were reporting and describing the sounds they would include. This corroborates the power of sound to evoke emotions.

\section{Conclusions}

Sound postcards can be used for eliciting the sounds that are specific to time and place, and meaningful to interviewees. Their descriptions contain information that is useful for understanding social dynamics at this time and in this place. In the present study, the use of sound postcards revealed changes in socio-acoustic dynamics before and after the interviewees' forced displacement. These changes confirm that sounds are essential to the affective and aesthetic properties of places, as proposed by Pistrick and Isnart (2013), and can therefore have a profound effect on our relationship with them. Our methodology was designed to identify the links between places, interviewees' perceptions of those places, and their associated emotions. The sound postcards enabled us to understand the interviewees' different networks, use of time and space, and the places in which they met, during each of three time periods: BFD, AFD, and at the time of data collection. We could observe that the domestic symphony associated with the countryside BFD evinces the bonds between the interviewees and their environment, be it nature, their networks, or the 
activities that filled their time. We could also observe the territorialisation of the countryside BFD characterised by the integrated sounds of human activities and nature.

The contrast between the sound environment of the country BFD and that of the city AFD shows that the victims of violence had not only had to deal with geographic issues but also to adapt to a way of life in which time and space are monopolised by human beings. The absence of nature, and consequent loss of their affective and subjective bonds with it, signalled a major change in their lives; it is clear that the sound territories of their destinations AFD were alien to them. Yet, faced with this loss, they discovered that the MFR could help them appropriate the new places in which they lived by learning and making music together. It also helped them re-territorialise these places through access to the MFR music centres as a shared space for meeting other people with whom new networks and positive experiences could be built. This process has been shown to help children adapt to their new contexts while also transforming their moods and providing new referents for them to rebuild their bonds with their environment.

Thus sounds and the relationships essential to their production have the capacity to create the place (Pistrick \& Isnart, 2013). Sounds can become the coordinates of belonging (Labelle, 2010); they make a vital contribution to the individual's level of intimacy with, and therefore sense of comfort in, their immediate environment. It is a major shift for a community that has experienced forced displacement to find in collective music making a sound experience that allows it to re-appropriate, at least to some extent, its spatio-temporal environment, enabling it to rediscover a sense of belonging that is key to the process of adapting to a new context.

\section{Acknowledgements}


The authors wish to thank the Batuta National Foundation for providing access to the music centres and the families and professionals interviewed. The authors acknowledge the Deontological Committee at the Universitat Jaume I for the positive report for ethical approval.

\section{Declaration of Conflicting Interests}

The author(s) declared the following potential conflicts of interest with respect to the research, authorship, and/or publication of this article: This article studied the Batuta National Foundation programme 'Music for Reconciliation' in Colombia. It formed part of the first author's PhD research undertaken between 2014 and April 2019. She now works with this organisation, but she was appointed to her position after concluding the thesis and the associated research papers.

\section{Funding}

The author(s) disclosed receipt of the following financial support for the research, authorship, and/or publication of this article: This work was supported by University Jaume I of Castelló, as part of the research project "Effects of the Creation of Group Music on the Reconstruction of the Social Fabric in Contexts of Exclusion and Extreme Violence" UJI-A2017-11, and by the Spanish Ministry of Science and Innovation, as part of the research project EDU2017-86311-P.

\section{ORCID iD}

Alberto Cabedo-Mas https://orcid.org/0000-0002-3703-3848 


\section{References}

Alonso-Cambrón, M. A. (2005). Sonido y sociabilidad: consistencia bioacústica en espacios públicos. Quaderns-e de l'Institut Català d'Antropologia, 5(a). https://www.raco.cat/index.php/QuadernseICA/article/view/51442.

Alonso-Cambrón, M. A. (2010). Etnografía sonora. Reflexiones prácticas. Sárasuati, 4, $26-33$.

Alonso-Cambrón, M. A. (2011). Socioacústica y etnografía urbana. Reflexiones en torno al caso de la Part Alta de Tarragona. Arxiu d'Etnografia de Catalunya, 11, 51-76. https://www.raco.cat/index.php/AEC/article/view/270416.

Alonso-Cambrón, M. A. (2014). Fai ruído unha árbore que cae se ninguén o escoita? Sobre a pertinencia da atención das Ciencias Sociales aos son. Fol de Veneno, Anuario de Antropoloxía e Historia de Galiza, 4.

Antonsich, M. (2010). Meanings of place and aspects of the Self: an interdisciplinary and empirical account. GeoJournal, 75(1), 119-132. https://doi.org/10.1007/s10708009-9290-9

Augé, M. (1993). Los no lugares: espacios del anonimato. Gedisa.

Augoyard, J. F. (1995). La sonorización antropológica del lugar. In M. J. Amerlinck (Ed.). Hacia una antropología arquitectónica. Universidad de Guadalajara.

Back, L. (2003). Deep Listening: researching music and the cartographies of sound. In M. Ogborn, A. Blunt, P. Gruffudd, \& D. Pinder (Eds), Cultural geography in practice (pp. 272-285). Arnold.

Barthes, R., \& Medrano, F. (1986). Lo obvio y lo obtuso. Paidós. 
Bergh, A., \& Sloboda, J. (2010). Music and art in conflict transformation: A Review. Music and arts in action, 2(2), 2-18.

Brandt, R., Duffy, M., \& MacKinnon, D. (Eds.). (2009). Hearing places: Sound, place, time and culture. Cambridge Scholars Press.

Butler, T. (2007). Memoryscape: How Audio Walks Can Deepen Our Sense of Place by Integrating Art, Oral History and Cultural Geography. Geography Compass, 1(3), 360- 372. https://doi.org/10.1111/J.1749-8198.2007.00017.X

Cabedo-Mas, A. (2015). Challenges and perspectives of peace education in schools: The role of music. Australian Journal of Music Education, 2015(1), 75-85.

Centro Nacional de Memoria Histórica, (2013). Informe Nacional Basta Ya. http://www.centrodememoriahistorica.gov.co/micrositios/informeGeneral/descar gas.html

Chaparro-Pacheco, R. \& Bello, M. (2010). El daño desde el enfoque psicosocial. Universidad Nacional de Colombia.

Daughtry, J. M. (2015). Listening to war: Sound, music, trauma, and survival in wartime Iraq. Oxford University Press.

Deleuze, G., \& Guattari, F. (1983). Anti-Oedipus: Capitalism and Schizophrenia. University of Minnesota Press.

Drever, J. (2007). Nostophonics' approaches to grasping everyday sounds from a UK perspective. In R. Bandt, \& M. Duffy, (Eds), Hearing Places, Sound, Place, Time and culture (pp.173-185). Cambridge Scholars Press.

Duffy, M. \& Waitt, G. (2011). Sound Diaries: a Method for Listening to Place. Aether Journal of media geography, 7, 119-136. 
Feld, S. (1984). Sound structure as social structure. Ethnomusicology, 28(3), 383-409. https://doi.org/10.2307/851232.

Feld, S. (1996). Waterfalls of song: An acoustemology of place resounding in Bosavi, Papua New Guinea. In S. Feld \& K. H. Basso (Eds.), Senses of place (pp. 91135). School of American Research Press.

Findlay-Walsh, I. (2018). Sonic Autoethnographies: Personal listening as compositional $\begin{array}{llll}\text { context. } & \text { Organised } & \text { Sound. }\end{array}$ https://doi.org/10.1017/S1355771817000371.

Forsey, M. (2008). Ethnography as participant listening. Ethnography Journal, 11(4), 558-572. https://doi.org/10.1177/1466138110372587

Fundación Nacional Batuta - BNF. (2016). Manual operativo para el programa Música para la Reconciliación. Colombian Ministry of Culture.

Gershon, W. S. (2011). Embodied knowledge: Sounds as educational Systems. Journal of Curriculum Theorizing, 27(2), 66-81.

Goodson, I. \& Gill, S. (2011). Narrative Pedagogy: Life History and Learning. Peter Lang

Grant, M. J., Möllemann, R., Morlandstö, I., Münz, C. S., \& Nuxoll, C. (2010). Music and Conflict: Interdisciplinary Perspectives. Interdisciplinary Science Reviews, 35(2), 183-198. https://doi.org/10.1179/030801810X12723585301237.

Hall, T., Lashua, B, \& Coffey, A. (2008). Sound and the Everyday in Qualitative Research. Qualitative Inquiry, 14(6), 1019-1040. https://doi.org/10.1177/1077800407312054. 
Hayden, F. G. (1982). Social fabric matrix: From perspective to analytical tool. Journal of Economic Issues, $\quad$ 637-662. https://doi.org/10.1080/00213624.1982.11504025.

Herreros Vázquez, F. (2004). ¿Por qué confiar? Formas de creación de confianza social. Revista mexicana de sociología, 66(4), 605-626.

Herreros Vázquez, F. (2007). Confianza y cooperación en ausencia del Estado. Revista internacional de sociología, $65 \quad$ (46), $\quad$ 87-105. https://doi.org/10.3989/ris.2007.i46.5.

Howell, G. (2018). Community music interventions in post-conflict contexts. In Bartleet, B. L., \& Higgins, L. (Eds.). The Oxford Handbook of Community Music (pp. 4370). $\quad$ Oxford University https://doi.org/10.1093/oxfordhb/9780190219505.001.0001.

Ibáñez, A. M., \& Velásquez, A. (2009). Identifying victims of civil conflicts: An evaluation of forced displaced households in Colombia. Journal of Peace Research, 46(3), 431-451. https://doi.org/10.1177/0022343309102661.

Kahn, D. (1999). Noise water meat: A history of sound in the arts. The MIT Press.

Krause, B. (2008). Anatomy of the soundscape: Evolving perspectives. Journal of the Audio Engineering Society, 56(1/2), 73-80.

Kvale, S. (2011). Las entrevistas en investigación cualitativa. Ediciones Morata.

Labelle, B. (2010). Acoustic Territories: Sound Culture and Everyday Life. Continuum Books. 
Lacey, J. (2016). Sonic Placemaking: Three approaches and ten attributes for the creation of enduring urban sound art installations. Organised Sound, 21(2), 147-159. https://doi.org/10.1017/S1355771816000078.

Lalive, C. (2008). La vida cotidiana: Construcción de un concepto sociológico y antropológico. Sociedad Hoy, 14, 9-31.

Lederach, J. P., \& Lederach, A. J. (2010). When Blood and Bones Cry Out: Journeys Through the Soundscape of Healing and Reconciliation. University of Queensland Press.

Llorca, J. (2014). Decibelios, experiencia y (re) presentación. Derivas metodológicas hacia el estudio del paisaje sonoro. Revista chilena de antropología visual, 23: $166-191$.

Llorca, J. (2017). Paisaje sonoro y territorio. El caso del barrio San Nicolás en Cali, Colombia. Revista INVI, 32(89), 9-59.

Lomax, A. (1976). Cantometrics: An approach to the anthropology of music. University of California Extension Media Center.

McCartney, A. (2010). Ethical questions about working with soundscapes. Soundscape, the Journal of Acoustic Ecology, 10(1), 24-26. https://doi.org/10.1017/S135577181600008X.

Nancy, J. L., (2007). Listening. Forham University Press.

Odena, O. (2013). Using software to tell a trustworthy, convincing and useful story. International Journal of Social Research Methodology, 16(5), 355-372. https://doi.org/10.1080/13645579.2012.706019. 
Osborne, N. (2012). Neuroscience and "real world" practice: music as a therapeutic resource for children in zones of conflict. Annals of the New York Academy of Sciences. 1252(1), 69-76. https://doi.org/10.1111/j.1749-6632.2012.06473.x.

Pécaut, D. (2001). Guerra contra la Sociedad. Editorial Planeta.

Perea, C. (2007). Con el diablo adentro. Pandillas, tiempo paralelo y poder. Siglo XXI Editores.

Pistrick, E., \& Isnart, C. (2013). Landscapes, soundscapes, mindscapes: Introduction. Etnográfica. Revista do Centro em Rede de Investigação em Antropologia, 17(3), 503-513. https://doi.org/10.4000/etnografica.3213.

Pitarch, J. E. A. (2004). Representación y cultura audiovisual en la sociedad contemporánea. Editorial UOC.

Polkinghorne, D. (1995). Narrative configuration in qualitative analysis. In J. Hatch, \& R. Wisniewski (Eds.), Life History and Narrative (pp. 5-23). The Falmer Press.

Pruitt, L. (2011). Music, youth, and peacebuilding in Northern Ireland. Peace \& Security, 23(2), 207-222. https://doi.org/10.1080/14781158.2011.580961.

Quiceno, N., \& Orjuela, C. (2017). Bojayá: memoria y horizontes de paz. Revista Colombiana de Sociología, $\quad 40 \quad$ (1): $\quad$ 103-127. https://doi.org/10.15446/rcs.v40n1 Supl.65909.

Rishbeth, C., \& Powell, M. (2013. Place attachment and memory: landscapes of belonging as experienced post-migration. Landscape research, 38(2), 160-178. https://doi.org/10.1080/01426397.2011.642344.

Robertson, C. (2019). Belief in the Power of Music and Resilient Identities: Navigating Shared Fictions. Music and Arts in Action, 7(1), 113-126. 
Rodríguez-Sánchez, A. (2010). Aportes de la música en los procesos de construcción de paz caso: Batuta - Meta y Unión Europea barrio La Reliquia. Villavicencio Colombia, Cuadernos de la especialización, 2. Universidad Nacional de Colombia.

Rodríguez-Sánchez, A. (2019). "Nos han enseñado a estar en compañía” Estudio de los programas musicales colectivos con comunidades víctimas del conflicto armado en Colombia como espacios de reconstrucción del tejido social. Doctoral Thesis. Universitat Jaume I, Castellón, Spain.

Rodríguez-Sánchez, A., \& Cabedo-Mas, A. (2017). Espacios musicales colectivos durante y después del conflicto armado como lugares de preservación del tejido social. Co-herencia, 14(26), 257-291. https://doi.org/DOI:10.17230/coherencia.14.26.10

Rodríguez-Sánchez, A., Cabedo-Mas, A., Zapata, G., \& Pinto, M. E. (2018). Artistic spaces for rebuilding social fabric. The Colombian case. In Walid Lutfy, M. \& Toffolo, C. (Eds.) Promoting Peace through Practice, Academia \& the Arts (pp. 251-277), IGI Global Editor.

Rodríguez-Sánchez, A., Odena, O., \& Cabedo-Mas, A. (2018). Using life histories with sound postcards to investigate a music programme for social reconstruction in Colombia. British Journal of Music Education, 35(2), 177-190. https://doi.org/10.1017/S0265051717000298

Rodríguez-Sánchez, A., \& Cabedo-Mas, A. (In press). Temporary musical identity as a tool for rebuilding social place. International Journal of Community Music, 13(3).

Rosenblum, E. (2013). If one night: an ethnographic soundscape and commentaries. Centre for imaginative ethnography. 
http://imaginativeethnography.org/galleria/if-one-night-an-ethnographicsoundscape-and-commentaries

Schafer, R. M. (1969). The new soundscape. BMI Canada Limited.

Schafer, R. M. (2013). El paisaje sonoro y la afinación del mundo. Intermedio.

Smith, J. A., Paul F., \& Michael L. (2009). Interpretative Phenomenological Analysis. Theory, Method and Research. SAGE Publishers.

Taussing, M. (2002). Chamanismo, colonialismo y hombre salvaje. Un estudio sobre el terror y la curación. Norma.

Truax, B. (2001). Acoustic communication. Ablex Pulishing.

Urbain, O. (Ed.). (2008). Music and Conflict Transformation: Harmonies and Dissonances in Geopolitics. I.B.Tauris.

Villa, M. I. (2006). Desplazamiento Forzado en Colombia, El miedo: un eje transversal del éxodo y de la lucha por la ciutadania. Corporación Región.

Westerkamp, H. (2002). Linking Soundscape Composition And Acoustic Ecology. Organised Sound, 7(1), 51-56. https://doi.org/10.1017/S1355771802001085

Wood, A. (2006). The Siren's Song: Sound, Conflict, and the Politics of Public Space in Tel Aviv. The Association for Jewish Studies Magazine. Spring/Summer Issue.

Zelizer, C. M. (2003). The Role of Artistic Processes in Peacebuilding in BosniaHerzegovina. Peace and Conflict Studies, 10(2), 62-75. 